\title{
RECORDS OF ANGLERFISHES (ACTINOPTERYGII: LOPHIIFORMES: LOPHIIDAE) FROM INDONESIA
}

\author{
Hsuan-Ching $\mathrm{HO}^{1,2^{*}}$, Toshio KAWAI ${ }^{3}$, WUDIANTO ${ }^{4}$, and Fayakun SATRIA ${ }^{4}$ \\ ${ }^{1}$ National Museum of Marine Biology and Aquarium, Pingtung, Taiwan. \\ ${ }^{2}$ Institution of Marine Biology, National Dong Hwa University, Pingtung, Taiwan \\ ${ }^{3}$ Fisheries Science Center, Hokkaido University Museum, Hakodate, Japan \\ ${ }^{4}$ Research Institute for Fisheries Enhancement and Conservation, Jatiluhur, Purwakarta, Indonesia
}

Ho H.-C., Kawai T., Wudianto, Satria F. 2016. Records of anglerfishes (Actinopterygii: Lophiiformes: Lophiidae) from Indonesia. Acta Ichthyol. Piscat. 46 (2): 77-85.

Background. The lophiid anglerfishes are with commercial importance, but rarely they are documented in Indonesian waters. During the Japanese and Indonesian collaborative surveys in 2004 and 2005, an anglerfish collection was made and it is the aim of this study to identify this collection, to document new records and to provide information further application usage such as fishery assessment from the study area.

Materials and methods. Specimens were deposited in the HUMZ collection and examined by the authors. Counts, measurements, and photography were consistent with the commonly used methods.

Results. Three genera and eight species in the family were collected, including Sladenia cf. zhui [sensu Ni, Wu et Li, 2012]; Lophiomus setigerus (Vahl, 1797); Lophiodes naresi (Günther, 1880); Lophiodes bruchius Caruso, 1981; Lophiodes endoi Ho et Shao, 2008; Lophiodes lugubris (Alcock, 1894); Lophiodes miacanthus (Gilbert, 1905); and Lophiodes triradiatus (Lloyd, 1909). Of these, Sladenia cf. zhui, L. bruchius, L. endoi, L. lugubris, and L. miacanthus, are described in detail.

Conclusion. The diversity of the lophiid anglerfish fauna is relatively low from the eastern Indian Ocean side of Indonesia. All species treated in the presently reported study represent the first records in Indonesian waters. A discussion of lophiid fauna from Indonesia is provided, along with a key to known species in Indonesia.

Keywords: taxonomy, teleostei, Lophiodes, Lophiomus, Sladenia

\section{INTRODUCTION}

The lophiid anglerfishes are commercially important fishes that inhabit the sea bottom at depths of several meters to about $1500 \mathrm{~m}$ in all major oceans. Some species in the genus Lophius can grow to ca. 1.5 meters total length and are sold as high-priced seafood, whereas most species attain about $40 \mathrm{~cm}$ and are of less commercial importance.

The family currently comprises four genera and about 28 valid species. About 14 species representative all four genera inhabit the Indo-west Pacific region (Caruso 1999; Ho et al. 2011, 2014). Only a few species were thought to occur in Indonesian waters, e.g. Lophiomus setigerus, Lophiodes gralicimanus and Lophiodes mutilus (Caruso 1999).

In 2004 and 2005, the Overseas Fishery Cooperation Foundation, Japan, and the Agency for Marine and Fisheries Research, Republic of Indonesia, conducted the Japan and Indonesia Deep Sea Fishery Resources Joint Exploration Project in deep waters off Sumatra and
Java, in the eastern Indian Ocean. The aim of this joint exploration was to identify and develop unused deep-sea fishery resources in this area. To accomplish this purpose, two cruises between 1 September and 30 October, 2004 and three cruises between 2 May and 14 August, 2005 were carried out by the Indonesian research vessel, Baruna Jaya IV. During this exploration, more than 400 fish species were collected (Ho et al. 2015, 2016).

Among the fishes collected were 10 specimens of the anglerfish family Lophiidae, representing seven species in three genera. The purpose of this publication is to document the occurrence of these species in Indonesian waters, to provide a detailed descriptions of each species, and to provide a key to their identification.

\section{METHODS AND MATERIALS}

Methods for taking measurements and the terminology used generally follow Caruso and Bullis (1976) and

* Correspondence: Dr. Hsuan-Ching Ho, No. 2, Houwan Rd., Checheng, Pingtung, Taiwan, phone:+886 882-5392, email: (HCH) ogcoho@gmail.com, (TK) kawai@museum.hokudai.ac.jp, (FS) fsatria_2@yahoo.com. 
Caruso (1981). In addition to those measurements used in the above references, the following measurements were recorded for Sladenia: eye diameter as the width of the clear window; inter-opercle and inter-palatine distances were measured from the outer base of the spines or bumps on both sides; upper jaw length is the distance from the upper jaw symphysis to lower margin of the maxilla; and caudal fin is measured from the posterior edge of the hypural to the distal margin of the fin. All specimens reported were deposited in the fish collection of Hokkaido University Museum, Hokadate (HUMZ). Institutional abbreviations follow those listed in the Catalog of Fishes (online version, Eschmeyer, 2016).

\section{RESULTS}

\section{Family Lophiidae Rafinesque, 1810} Genus Sladenia Regan, 1908

Sladenia Regan, 1908: 250 (type species: Sladenia gardineri Regan, 1908, by monotypy).

Remarks. This is a very poorly known genus with four nominal species, none of which are well represented in collections. The known species have been described from few specimens and individual variation is still poorly understood. The two specimens from the current collection resemble a recently described species, Sladenia chui $\mathrm{Ni}, \mathrm{Wu}$ et $\mathrm{Li}, 2012$. However, since there are some differences, the identification is only tentative.

Underwater photographs taken by submersibles show individuals of Sladenia on rocks, rocky areas or deep coral reefs, which may explain the relatively few specimens in collections. This is new record for the genus in Indonesian waters.

\section{Sladenia cf. zhui [sensu Ni, Wu et Li, 2012]}

Fig. 1, Table 1

Materials. HUMZ $191110 \quad(1,263), \quad 8^{\circ} 40.3^{\prime} \mathrm{S}$, $111^{\circ} 15.5^{\prime} \mathrm{E}-8^{\circ} 40.5^{\prime} \mathrm{S}, 111^{\circ} 14.2^{\prime} \mathrm{E}$, off Java, Indonesia, 680-706 m, 10 Sep. 2004. HUMZ 191516 (1, 270), $8^{\circ} 20.1^{\prime} \mathrm{S}, \quad 109^{\circ} 54.2^{\prime} \mathrm{E}-8^{\circ} 19.3^{\prime} \mathrm{S}, 1^{\circ} 9^{\circ} 53.3^{\prime} \mathrm{E}$, off Java, Indonesia, 850-916 m, 12 Sep. 2004.

Description. Morphomeric data are provided in Table 1. Dorsal fin rays 9 ; pectoral fin rays 18 ; anal fin rays 6 ; caudal fin rays 9 .

Body slightly elongate, rather muscular, with slight hump on back. Head globular. Tail strong and cylindrical, gradually compressed posteriorly. Mouth large, its cleft oblique to nearly vertical. Lower jaw extended forward, well in advance of the upper jaw; posterior end of upper jaw not reaching vertical at anterior margin of eye. Eye relatively small, covered by transparent skin, directed laterally and slightly dorsally.

Anterior portion of frontal with flat dorsal process, its anterior end slightly elevated; posterior portion of frontal with plate-like process directed outward laterally, forming a right angle. Frontal and sphenotic spines both relatively blunt, but better developed than other cranial spines. Dorsal surface of premaxilla, palatine, outer sphenoid, pterotic, dorsal end of opercle, hyomandibula and quadrate with visible/feeble low bumps. Blunt, broad-based symphysial

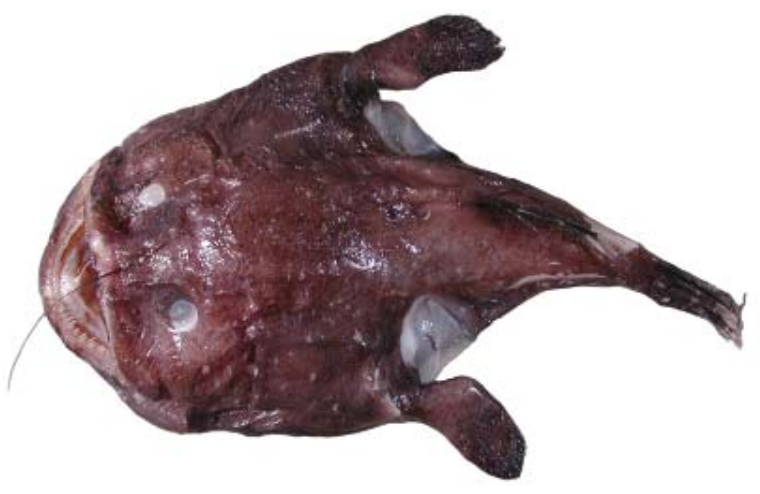

Fig. 1. Sladenia cf. chui, HUMZ 191110, $263.0 \mathrm{~mm}$ SL, fresh specimen; Photo by T. Kawai

Table 1

Morphometric data of two Indonesian specimens of Sladenia cf. zhui

\begin{tabular}{lrrrr}
\hline & HUMZ & 191110 & HUMZ & 191516 \\
\hline Standard length [SL] & \multicolumn{2}{c}{$263 \mathrm{~mm}$} & \multicolumn{2}{c}{$270 \mathrm{~mm}$} \\
\hline & \%SL & \%HL & \%SL & $\% \mathrm{HL}$ \\
Head length & 32.5 & 100.0 & 33.3 & 100.0 \\
Head depth & 29.5 & 90.7 & 29.9 & 89.8 \\
Predorsal length & 59.6 & 183.5 & 57.0 & 171.3 \\
Illicial length & 36.0 & 111.0 & 37.0 & 111.4 \\
2nd dorsal-fin spine length & 19.7 & 60.7 & 15.9 & 47.9 \\
Pre-preopercle length & 32.2 & 99.2 & 31.3 & 94.1 \\
Snout length & 19.3 & 59.5 & 19.3 & 57.9 \\
Snout width & 8.5 & 26.1 & 9.2 & 27.7 \\
Eye diameter & 5.9 & 18.0 & 4.9 & 14.7 \\
Upper-jaw length & 29.2 & 89.9 & 27.3 & 82.2 \\
Inter-palatine with & 13.6 & 41.8 & 14.1 & 42.4 \\
Inter-frontal width & 11.1 & 34.1 & 10.6 & 32.0 \\
Inter-sphenotic width & 17.1 & 52.8 & 18.7 & 56.3 \\
Inter-pterotic width & 24.9 & 76.8 & 25.9 & 78.0 \\
Inter-opercular width & 33.5 & 103.2 & 33.1 & 99.4 \\
Distance between pterotic & 8.9 & 27.3 & 9.7 & 29.1 \\
and sphenotic spines & & & & \\
Distance between upper & 23.6 & 72.7 & 26.6 & 80.0 \\
palatine and quadrate spines & & & & \\
Caudal peduncle depth & 13.0 & 40.0 & 13.6 & 41.0 \\
Tail length & 26.4 & 81.4 & 31.7 & 95.4 \\
Caudal-fin length & 32.2 & 99.3 & 33.3 & 100.0 \\
\hline & & & &
\end{tabular}

spine on lower jaw. Preopercle, subopercle, humeral, parietal and articular without spines or bumps.

Illicium slender and filamentous, its length 36.0 $37.0 \%$ SL; no esca; second dorsal spine short, 15.9-19.7\% SL, about half length of illicium. Two post-cephalic spines, almost completely contained within loose fold of skin. Soft dorsal fin base short, at posterior one-third of body, covered by loose skin from base to about two-thirds of its height, proximal half of posterior margin of last ray connected by loose skin to base of caudal fin. Pectoral-fin base with long pterygial bones, its length about two times that of longest fin ray. Anal fin covered by loose skin from base to about three-fourths of its height, proximal half of posterior margin of last ray connected by loose skin to 
base of caudal fin. Dorsal- and anal- fin rays extending far beyond base of caudal fin when fully reclined. Pelvic fin bone long, about same length as longest fin ray; pelvic fin covered by thick skin.

Gill opening very large, extending well in front of pectoral-fin base, only narrowly connected to body wall by skin on dorsal surface of pectoral elbow.

Teeth on vomer and palatine conical to fanglike, distinctly larger than those on jaws. Two to four teeth on each side of vomer; largest teeth, usually innermost, fixed, the rest depressible. Single irregular row of 6-7 teeth on palatine. Upper jaw with outer row of smaller teeth along entire length; short, irregular rows of slightly larger teeth along inner one-third of jaw, innermost tooth largest and fixed, the rest depressible. Lower jaw with about 3-4 rows of depressible teeth, those on inner row longest.

Opercle deeply forked, both lobes about equal in length. Subopercle slender, overlaps by the lower end of lower branch of opercle; dorsal margin of subopercle with bluntly pointed process, anterior end bluntly pointed, posterior portion slender and tapering, filamentous distally. Coloration. Uniformly brownish. Margins around mouth, including space between maxilla and premaxilla and lower lip pale. Peritoneum black. Mouth cavity pale, with some light grayish patches on floor of mouth and/or tongue.

Remarks. The presence of two post-cephalic spines and the uniformly brown coloration indicate a close resemblance between the two Indonesian specimens and $S$. chui. However, Ni et al. (2012) diagnosed S. chui by its very broad snout (11.7-13.1\% SL or 29.2-34.6\% of head length), whereas the Indonesian specimens have a narrow snout (8.5-9.2\% SL and $26.1-27.2 \%$ of head length, respectively) that falls within the range of other congeners. In fact, the snout width provided by Ni et al. (2012) is far broader than any lophiid species and that may be attributed to different landmarks interpreted by the authors. An attempt to examine the type series in the Shanghai Ocean University has been unsuccessful.

Sladenia gardineri Regan 1908 also has two postcephalic spines. However, our specimens are slightly smaller than the holotype of $S$. gardineri and differ from it in having uniformly brown coloration (vs. relatively fine pale vermiculations on dorsal surface), smaller head $(32.5 \%-33.3 \%$ SL vs. $41.4 \%$ SL), longer illicium (36.0 $37.0 \%$ SL vs. $31.5 \%$ SL), and longer second dorsal spine (15.9-19.7\% SL vs. $10.4 \%$ SL).

\section{Lophiomus Gill, 1883}

Lophiomus Gill, 1883:552 (type species: Lophius setigerus Vahl, 1797, by original designation; monotypic).

Remarks. A single species widespread in the Indo-west Pacific Ocean, including Indonesia.

\section{Lophiomus setigerus (Vahl, 1797)}

Fig. 2, Table 2

Lophius setigerus Vahl, 1797: 215, pl. 3, figs. 5-6 (type locality: possible China).

Table 2

Morphometric data, as expressed in percentage of standard length, of lophiid species examined in this study

\begin{tabular}{lcccccc}
\hline & $\begin{array}{c}\text { Lophiomus } \\
\text { setigerus }\end{array}$ & $\begin{array}{c}\text { Lophiodes } \\
\text { naresi }\end{array}$ & $\begin{array}{c}\text { Lophiodes } \\
\text { bruchius }\end{array}$ & $\begin{array}{c}\text { Lophiodes } \\
\text { endoi }\end{array}$ & $\begin{array}{c}\text { Lophiodes } \\
\text { triradiatus }\end{array}$ & $\begin{array}{c}\text { Lophiodes } \\
\text { miacanthus }\end{array}$ \\
\hline Standard length [mm] & $179-236$ & 243 & 141 & 130.1 & 50.4 & 86.3 \\
Number of specimens & 2 & 1 & 1 & 1 & 1 & 1 \\
Head length & $34.1-36.4$ & 32.6 & 40.1 & 38.4 & 34.3 & 37.7 \\
Illicial length & $29.8-32.5$ & 22.8 & 31.1 & 25.7 & 17.9 & 25.3 \\
2nd dorsal-fin spine & $19.7-21.6$ & 29.5 & 34.0 & 30.2 & 15.5 & 37.8 \\
3rd dorsal-fin spine & $11.0-20.6$ & 34.9 & 48.6 & 39.1 & 18.3 & 41.3 \\
4th dorsal-fin spine & $14.0-14.9$ & 25.6 & absent & absent & absent & absent \\
5th dorsal-fin spine & $9.3-9.8$ & 19.8 & 10.6 & 16.3 & absent & 12.4 \\
6th dorsal-fin spine & $8.2-8.4$ & 11.0 & 5.2 & 9.1 & absent & 9.3 \\
Tail length & $29.9-31.9$ & 25.8 & 20.4 & 27.1 & 29.4 & 20.6 \\
Head width & $57.6-58.5$ & 52.5 & 59.5 & 55.4 & 83.8 & 64.0 \\
Head depth & $72.0-79.4$ & 68.1 & 73.0 & 66.4 & 80.3 & 76.0 \\
Inter-sphenotic width & $51.1-51.5$ & 41.2 & 46.8 & 45.2 & 56.6 & 46.8 \\
Inter-frontal width & $35.5-39.3$ & 27.6 & 43.6 & 39.0 & 41.0 & 45.8 \\
Snout length & $59.4-63.7$ & 59.6 & 59.4 & 57.8 & 59.5 & 62.8 \\
Snout width & $22.0-25.7$ & 19.8 & 22.8 & 20.0 & 22.0 & 23.4 \\
Inter-palatine width & $41.8-43.5$ & 36.1 & 41.3 & 39.6 & 42.2 & 43.1 \\
Distance between pterotic & $17.5-18.4$ & 18.9 & 20.0 & 18.2 & 26.0 & 23.4 \\
and sphenotic spines & & & & & & 72.0 \\
Distance between palatine & $64.2-69.50$ & 73.1 & 71.7 & 72.0 & 74.6 & 78.5 \\
and quadrate spines & & & & & & 45.1 \\
Distance between opercular & $50.7-3.7$ & 46.0 & 43.1 & 45.2 & 42.8 & 46.5 \\
and subopercular spines & & & & & & \\
\hline
\end{tabular}


Lophiomus setigerus (Vahl, 1797): Caruso 1999: 2011. Ho et al. 2011: 1722.

Materials. HUMZ $191183(1,236)$ and HUMZ 191184 $(1,179), 8^{\circ} 6.17^{\prime} \mathrm{S}, 108^{\circ} 34.05^{\prime} \mathrm{E}-8^{\circ} 4.22^{\prime} \mathrm{S}, 108^{\circ} 34^{\prime} \mathrm{E}$, off Java, Indonesia, 180-210 m, 6 Sep. 2004.

Description. Morphometric data are provided in Table 2. Dorsal fin rays 7 or 8; pectoral fin rays 23 or 24; anal fin rays 6 ; caudal fin rays 9 .

Body depressed, forming rounded disk comprising head and anterior portion of body; tail muscular, depressed. Dorsal surface of frontal and premaxilla with low knoblike spines. Palatine with 2 spines, posterior distinctly larger than anterior. Upper end of each premaxilla with a bifurcate spine, smaller than those of palatine. Blunt symphysial spine on lower jaw. Two sharp spines posteriorly on posterior margin of frontals.

Two sharp spines on sphenotic, outer about twice size of inner. Inner frontal spine a feeble bump. Hyomandibular spines reduced in larger specimen, slightly developed in smaller. Pterotic spines blunt with broad base. A sharp spine halfway onto preopercle. Lower end of subopercle with sharp spine. Single epiotic spine well developed. Humeral spine well developed, multifid.

Illicium reaching slightly beyond epiotic spines. Second dorsal-fin spine shorter than illicium, with very broad pigmented membranes, reaching inner sphenotic spines in small specimen, extending to slightly beyond the spines in larger specimen. Third dorsal-fin spine short in larger specimen, which might be result of damage, reaching humeral spine; longer in smaller specimen, reaching slightly beyond base of sixth dorsal spine. Fourth dorsal-fin spine slender, slightly beyond tip of following two spines. Fifth and sixth dorsal-fin spines short, mostly covered by skin, both not reaching origin of soft dorsal fin. When fully folded back, anal fin not reaching base of caudal fin.

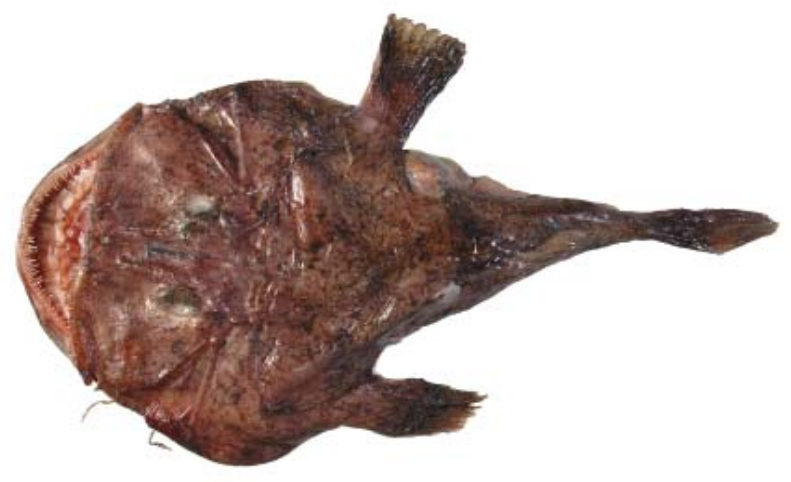

Fig. 2. Lophiomus setigerus (Vahl, 1797), HUMZ 191183, $236.0 \mathrm{~mm}$ SL, fresh specimen; Photo by T. Kawai

Coloration. Dorsal surface light brown to deep brown; with small pigmentation; dorsal surface of pectoral fin darker; dorsal fin paler; ventral surface of body pale, or very weakly grayish on caudal peduncle; anal fin pale; peritoneum black.

Distribution. Widespread in Indo-west Pacific Ocean.

\section{Lophiodes Goode et Bean, 1896}

Lophiodes Goode et Bean, 1896: 537 (type species: Lophius mutilus Alcock, 1894, by monotypy).

Remarks. The most specious genus of the family, with 17 nominal species distributed in all major oceans. Five species from Indonesian waters are recognized in this study.

\section{Lophiodes naresi (Günther, 1880)}

Fig. 3, Table 2

Lophius naresi Günther, 1880: 56, pl. 25 (type locality: Nares harbor, Admiralty Islands, Challenger station 219, depth $278 \mathrm{~m})$.

Lophiodes naresi (Günther, 1880): Caruso 1981: 530.

Ho and Shao 2007: 24. Ho et al. 2011: 1739.

Material. HUMZ $193654 \quad(1,243), \quad 8^{\circ} 4.7^{\prime} \mathrm{S}$, $108^{\circ} 24.7^{\prime} \mathrm{E}-8^{\circ} 4.4^{\prime} \mathrm{S}, 108^{\circ} 23.4^{\prime} \mathrm{E}$, off Java, Indonesia, 246-263 m, 4 May 2005.

Description. Morphometric data are provided in Table 2 . Dorsal fin rays 8 ; pectoral fin rays 15 ; anal fin rays 6 ; caudal fin rays 9 .

Body depressed, head broad; oval in dorsal view. Dorsal surfaces of frontal and premaxilla smooth, without bumps, except for low bump on dorsal surface of upper portion of premaxilla. Posterior margin of frontal bluntly serrate, posteriormost spine directed slightly outward.

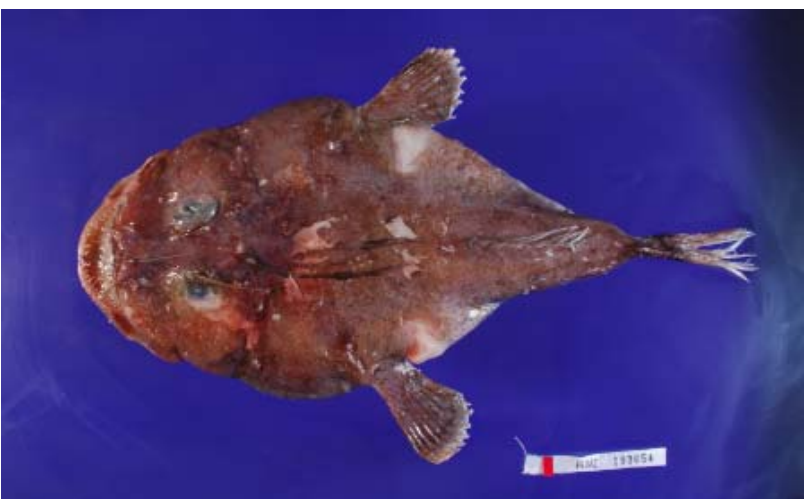

Fig. 3. Lophiodes naresi (Günther, 1880), HUMZ 193654, 243.0 mm SL, fresh specimen; Photo by T. Kawai

Palatine spines well developed, posterior spine about twice length of anterior one. Sphenotic with sharp spine, directed slightly backwards. Hyomandibular spine a low bump. Inner frontal spine absent. Opercular spine blunt. Preopercular spine short, but sharp. Articular and quadrate spines low bumps. Subopercular spine short and blunt. Pterotic spine a bump. Cleithrum with blunt spine. Humeral spine bifurcate on right side, simple on left side. Other spines on head either reduced and feeble, or absent.

Illicium reaching slightly beyond base of third dorsalfin spine. Illicium with terminal flap and two small eyelike bulbs; no tendrils on stem. Second to sixth dorsal-fin spines present, relatively strong, tendrils on all spines. Second dorsal-fin spine reaching cleithral spine. Third dorsal-fin spine very strong, with large tendrils, not reaching origin of soft dorsal fin. Fourth and fifth dorsalfin spines reaching to base of second soft dorsal-fin ray. 
Sixth dorsal-fin spine short, about half length of fifth, not reaching origin of soft dorsal fin.

Upper jaw with long outer row of small fangs, those on medial portion directed forward and downward; short irregular inner row of teeth on medial one-third of jaw, slightly larger than those of outer row, innermost teeth on each side fixed, the rest depressible. All teeth on vomer and palatine fixed, teeth present on outer corner of vomer and along palatine. Lower jaw with about 4 rows of teeth, those on inner row longest. Anal fin reaching base of caudal fin when fully folded back.

Coloration. Dorsal surface uniformly brownish, with some dark flaps. Pectoral fin slightly darker than body, with broad white margin. Dorsal fin slightly paler than body. Ventral surface paler than that of dorsal surface, but with fine pigmentation. Pelvic fin with base slightly darker than rest fin and with broad white margin; caudal fin base deep brown, paler distally.

Distribution. Majority of specimens collected from western and central Pacific Ocean. Our specimen was collected in the eastern Indian Ocean off Indonesia, which represents the first record of this species in the area.

Remarks. This species is easily confused with a similar species, Lophiodes insidiator. Records of the latter from western Pacific Ocean need further investigation.

\section{Lophiodes bruchius Caruso, 1981}

Fig. 4, Table 2

Lophiodes bruchius Caruso, 1981: 539, fig. 13B (type locality: north of Maui Island, Hawaiian Islands, $\left.21^{\circ} 03.5^{\prime} \mathrm{N}, 156^{\circ} 29.1^{\prime} \mathrm{W}, 274-318 \mathrm{~m}\right)$. Ho and Shao 2008: 371. Ho et al. 2011: 1733.

Material. HUMZ 193649 (1, 141), $8^{\circ} 19.2^{\prime} \mathrm{S}$, $109^{\circ} 45.7^{\prime} \mathrm{E}-8^{\circ} 19.1^{\prime} \mathrm{S}, 109^{\circ} 44.0^{\prime} \mathrm{E}$, off south coast of Java, Indonesia, 335-400 m, 10 May 2005.

Description. Morphometric data are provided in Table 2 . Dorsal fin rays 8 ; pectoral fin rays 21 ; anal fin rays 6 ; caudal fin rays 9 .

Body depressed, tail muscular, laterally depressed; head broad, oval in dorsal view. Dorsal surface of frontal and premaxilla smooth, without bumps, except for a small bump on dorsal surface of upper portion of premaxilla. Posterior frontal ridge with 3 spines, posteriormost largest, sharp, slightly curved laterally. Inner frontal spine present.

Palatine with 2 sharp spines, posterior spine bout twice length of anterior one. Sphenotic with two spines, inner spine sharp and long, straight; outer spine short and pointed on right side, blunt on left side. Hyomandibular with two short but sharp spines, posterior spine larger. Opercular spine short but sharp. Preopercular spine sharp and long. Two spines on subopercle, outer about twice length of inner. Humeral spine subdivided into four spines distally. Blunt spine on quadrate. Two blunt spines on articular. Cleithral spine blunt.

Illicium reaching slightly beyond base of third dorsalfin spine. Esca a small bulb, bearing distal cirrus. Second dorsal-fin spine reaching cleithral spine. Third dorsal-fin spine broken distally, remaining part extending to base of sixth soft dorsal-fin ray. Half of fifth dorsal-fin spine exposed, short, not reaching origin of soft dorsal fin. Sixth dorsal spine completely embedded in skin.

Teeth on vomer and palatines about same size of those on jaws. Teeth on premaxilla arranged in longer row on outer margin, those on inner portion of premaxilla slightly longer and directed forward; a short posterior row of slightly longer teeth on inner one-third of bone, the innermost tooth (second innermost on right side) fixed, the remaining teeth depressible. Lower jaw with three rows of straight teeth, those in innermost row longest. Anal fin extending well beyond the caudal fin base when fully folded back.

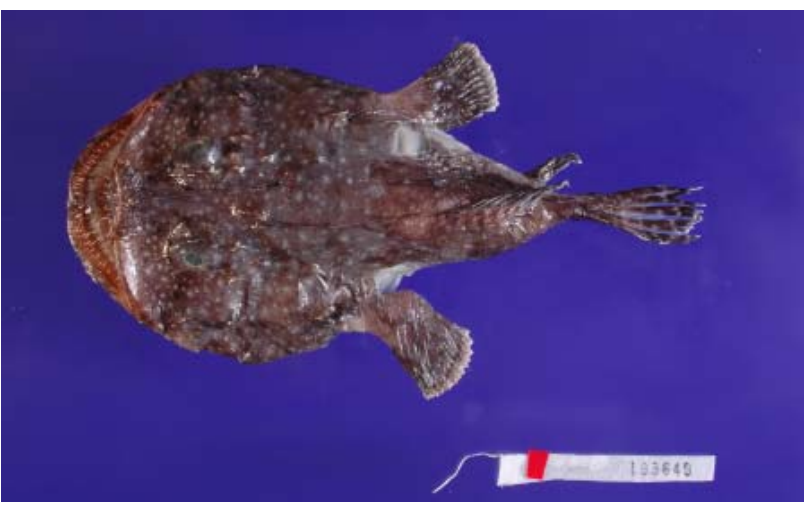

Fig. 4. Lophiodes bruchius Caruso, 1981, HUMZ 193649, 141.0 mm SL, fresh specimen; Photo by T. Kawai

Coloration. Body uniformly deep brown; dorsal surface of pectoral fin darker, with pale margin. Some small, pale spots, each with a black cirrus on its dorsal surface. Some irregular black patches on dorsal surface. Ventral surface lightly pigmented. Peritoneum black. Tip of esca black, including cirrus.

Distribution. Previously known from the northern and central Pacific Ocean with a single record from Polynesia. Our specimen represents the first record of the species in the eastern Indian Ocean.

Remarks. Ho et al. (2011) reported a specimen of this species from the Marquesas Islands of Polynesia, whereas all other specimens were obtained from the Kyushu-Palau Ridge and Hawaiian Islands (Ho and Shao 2008). They (Ho et al. 2011) indicated the differences in the Marquesas specimen: a single terminal cirrus on the esca (vs. more than 5 in the northern Pacific specimens) and one extra pair of small tendrils on the third dorsal-fin spine (vs. only one pair of tendrils). The Indonesian specimen also has only one terminal cirrus on the esca. However, the skin of the third dorsal-fin spine of this specimen is damaged and tendrils have been lost.

\section{Lophiodes endoi Ho et Shao, 2008}

Fig. 5, Table 2

Lophiodes endoi Ho et Shao, 2008: 368, figs. (type

locality: north-eastern Taiwan, north-western Pacific, 280-310 m). Ho and Shao 2011: 37. Ho et al. 2011: 1734. Material. HUMZ 193756 (1, 130), st. 7, 8¹2.6's, $109^{\circ} 11.6^{\prime} \mathrm{E}-8^{\circ} 12.8^{\prime} \mathrm{S}, 109^{\circ} 9.8^{\prime} \mathrm{E}$, off Java, Indonesia, 280-300 m, 6 May 2005. 


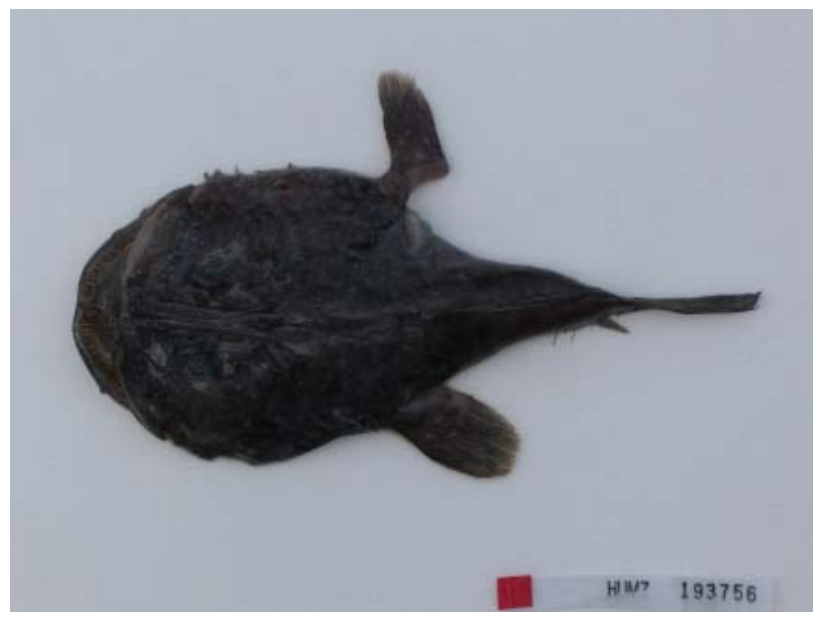

Fig. 5. Lophiodes endoi Ho et Shao, 2008, HUMZ 193756, $130.1 \mathrm{~mm}$ SL, fresh specimen; Photo by T. Kawai

Description. Morphometric data are provided in Table 2 . Dorsal fin rays 8 ; pectoral fin rays 21 ; anal fin rays 6 ; caudal fin rays 9 .

Body depressed, tail muscular, laterally depressed; head broad, oval in dorsal view. Dorsal surfaces of frontal and premaxilla smooth, except for bump on dorsal surface of inner portion of premaxilla. Posterior frontal ridge with 3 sharp, slightly curved laterally spines; posterior spine slightly larger than the other two. Inner frontal spine present.

Palatine with 2 sharp spines, posterior about three times size of anterior spine. Sphenotic with two spines, inner spine sharp and long, straight; outer spine short and pointed on right side, blunt on left side. Hyomandibula with two short, sharp spines, posterior spine larger. Opercle with short, sharp spine. Preopercle with sharp spine. Two spines on subopercle, posterior about twice size of anterior spine. Humeral spine divided into 4 branches distally. Quadrate with blunt spine. Articular with two blunt spines. Cleithral spine blunt.

Illicium reaching nearly base of third dorsal-fin spine. Esca a small rounded bulb. Second dorsal-fin spine reaching slightly beyond base of third dorsal-fin spine. Third dorsal-fin spine reaching base of fifth ray of soft dorsal fin, pair of dark tendrils at about two-third spine length above the base of spine, two additional small black tendrils at distal one-fourth of spine (shrunk and unclear if paired). Fifth dorsal-fin spine mostly exposed, long, reaching base of second ray of soft dorsal fin. Half of sixth dorsal-fin spine exposed, reaching origin of soft dorsal fin.

Two teeth on each lateral corner of vomer; palatines with an irregular row of 8 teeth. Teeth on maxilla in one outer row; those on mesial side slightly longer and directed forward; short inner row of teeth with slightly longer teeth than those of outer row, all depressible, except for second innermost of right side (none on left side) fixed. Lower jaw with three rows of teeth, those of innermost row longest. Anal fin extending well beyond caudal-fin base when folded back.
Coloration. Body uniformly deep brown; dorsal surface of pectoral fin darker with pale margin. Dorsal surface with some small pale spots, each with black cirrus. Ventral surface lightly pigmented. Peritoneum black. Color of esca matching dorsal background.

Distribution. Previously known from the western and southern Pacific Ocean off Japan, Taiwan and New Caledonia, and from eastern Indian Ocean off western Australia. The specimen represents a new record for Indonesia.

Remarks. Although the third dorsal-fin spine of the Indonesian specimen is slightly shrunken, it clearly has two black skin patches on the upper one-third of the spine. As mentioned in Ho et al. (2011), the only specimen of L. bruchius collected in Polynesia also has one additional pair of small tendrils on the distal portion of the spine. This difference may represent geographic variation.

\section{Lophiodes triradiatus (Lloyd, 1909)}

Fig. 6, Table 2

Lophius triradiatus Lloyd, 1909: 166 (type locality:

Laccadive Sea, $10^{\circ} 08^{\prime} 43^{\prime \prime} \mathrm{N}, 75^{\circ} 33^{\prime} 30^{\prime \prime} \mathrm{E}$, Investigator station $259,549 \mathrm{~m})$.

Lophiodes triradiatus (Lloyd, 1909): Ho et al. 2014: 587.

Lophiodes infrabrunneus Smith et Radcliffe, 1912:

Ho et al. 2009: 63.

Material. HUMZ 193697 (1, 50.4), 4³4.0'S, $101^{\circ} 9.5^{\prime} \mathrm{E}-4^{\circ} 34.9^{\prime} \mathrm{S}, 101^{\circ} 10.5^{\prime} \mathrm{E}$, off Sumatra, Indonesia, 735-750 m, 9 Jun. 2005.

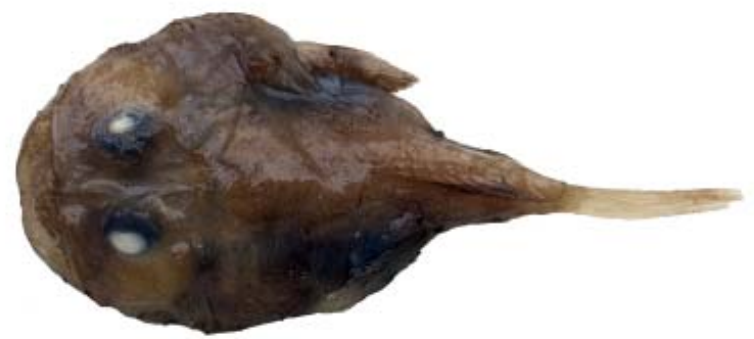

Fig. 6. Lophiodes triradiatus (Lloyd, 1909), HUMZ 193697 , $50.4 \mathrm{~mm} \mathrm{SL}$, preserved

Remarks. A name treated as nomen dubium of Lophiodes by Caruso (1981) and Ho et al. (2009). Ho et al. (2014) resurrected the name and recognized it as senior synonym of Lophiodes infrabrunneus Smith et Radcliffe, 1912.

This species can be easily separated from congeners by its three dorsal-fin spines and lack of all post-cephalic spines. Detailed descriptions were provided by Ho et al. (2009, 2014).

\section{Lophiodes miacanthus (Gilbert, 1905)}

Fig. 7, Table 2

Lophiomus miacanthus Gilbert, 1905: 691, fig. 273 (type locality: off Oahu Island, Hawaiian Islands, 463-516 m). 
Material. HUMZ 193939 (1, 86.3), $2^{\circ} 51.8^{\prime} \mathrm{N}$, $95^{\circ} 5.3^{\prime} \mathrm{E}-2^{\circ} 50.9^{\prime} \mathrm{S}, 95^{\circ} 4.3^{\prime} \mathrm{E}$, off Sumatra, Indonesia, 519-581 m, 13 June 2005.

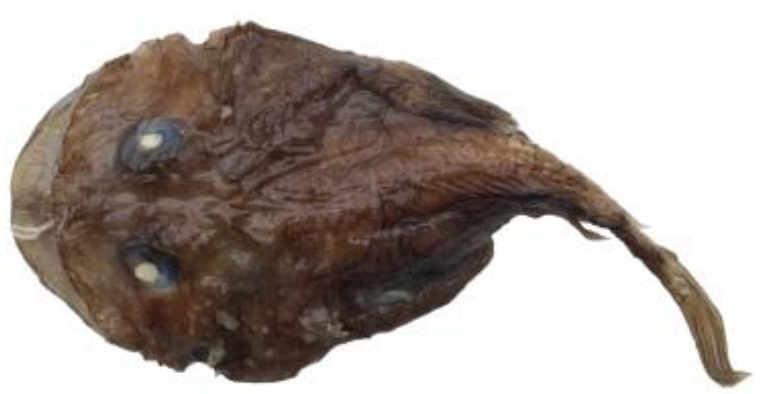

Fig. 7. Lophiodes miacanthus (Gilbert, 1905), HUMZ 193939, $86.3 \mathrm{~mm} \mathrm{SL}$, preserved

Lophiodes miacanthus (Gilbert, 1905): Caruso 1981: 541. Ho and Shao 2007: 26. Ho and Shao 2008: 371. Ho et al. 2011: 1736.

Description. Morphometric data are provided in Table 2 . Dorsal fin rays 8 ; pectoral fin rays 18 ; anal fin rays 6 ; caudal fin rays 9 .

Body depressed; tail muscular, laterally depressed. Head broad, rounded in dorsal view. Dorsal surfaces of frontal and premaxilla smooth without bumps. Posterior frontal ridge with 3 spines, all blunt.

Palatine with two sharp spines, posterior slightly larger than anterior spine. Inner sphenotic spine sharp and long, straight; outer sphenotic spine blunt, broad. Hyomandibula with two short, sharp spines, anterior spine larger. Opercle with short blunt spine. Preopercle with long sharp spine on left side; spine absent on right side. Two spines on subopercle, posterior spine slightly larger than anterior spine. Humeral spine divided into 4 branches. Quadrate with blunt spine. Articular with two blunt spines. Cleithral spine blunt.

Illicium reaching slightly beyond base of sphenotic spines, but not reaching base of third dorsal-fin spine. Esca a small narrow bulb, with terminal cirrus. Second dorsal-fin spine reaching base of humeral spines. Third dorsal-fin spine reaching base of fifth ray of soft dorsal fin; no clear black tendril on spine, but some transparent membrane present. Fifth and sixth dorsal-fin spines exposed distally, not reaching origin of soft dorsal fin. Dorsal surfaces of frontal and premaxilla smooth, without bumps. Posterior frontal ridge with 3 spines; posteriormost spine sharp, slightly curved outwardly, and slightly larger than the other two spines. Inner frontal spine present. Palatine with two sharp spines, posterior spine about twice size of anterior one.

Two teeth on each lateral corner of vomer; irregular row of 8 or 9 teeth on palatine; all teeth fixed. Teeth on maxilla with outer row on margin, those on mesial side slightly longer and directed forward; one short irregular inner row, slightly longer than that of outer row; innermost tooth fixed, others depressible. Lower jaw with three rows of straight depressible teeth, those in innermost row longest. Anal fin extended well beyond the caudal fin base when fully laid back.
Coloration. Body uniformly deep brown with many irregular black patches; dorsal surface of pectoral fin darker, with pale margin. Illicium, second and third dorsal spines deep brown. Esca transparent. Ventral surface brownish gray. Peritoneum black.

Distribution. Previously known from the central north, northwestern and tropical Pacific Ocean. New record for Indonesia.

Remarks. Ho and Shao $(2007,2008)$ recorded this species from Taiwan and Kyushu-Palau Ridge, respectively, and Ho et al. (2011) recorded this species from the tropical Pacific Ocean. In contract to specimens from elsewhere, the illicium of the Indonesian specimen is brownish, rather than black and this specimen has only 18 rays in each pectoral fin. The black color of other specimens of L. miacanthus do not appear to fade after preservation and the relatively few pectoral-fin rays have not been observed in previous studies (19 or 21 in Caruso 1981; 22 in Ho et al. 2011). As more specimens may support the recognition of the Indonesian population as a different species, the identification is regarded as provisional.

\section{Lophiodes lugubris (Alcock, 1894)}

Fig. 8

Lophius lugubris Alcock, 1894: 118 (type locality: 13.5 miles north $64^{\circ}$ west of Columbo Light House, Sri Lanka, Investigator station 151, 256-732 m). Caruso 1981: 538 (regarded a synonym of Lophiodes mutilus). Material. HUMZ 190869 (1, 41.6), 3²4.19'S, $100^{\circ} 21.06^{\prime} \mathrm{E}-3^{\circ} 23.44^{\prime} \mathrm{S}, \quad 100^{\circ} 19.56^{\prime} \mathrm{E}$, off Sumatra, Indonesia, 396-453 m, 28 September 2004.

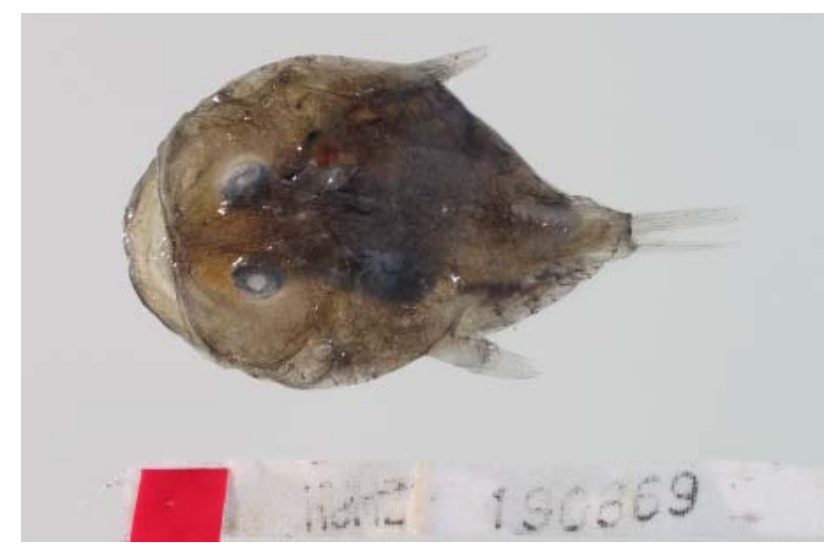

Fig. 8. Lophiodes lugubris (Alcock, 1894) HUMZ 190869 , 41.6 mm SL, fresh; Photo by T. Kawai

Remarks. The specimen examined is a juvenile with welldeveloped fins and spines. It has only one post-cephalic spine (assumed to be the fifth dorsal-fin spine) and has no trace of the last dorsal-fin spine (assumed to be sixth). Alcock (1894) described Lophius lugubris from India, which he diagnosed as having only four dorsal-fin spines (i.e. only one post-cephalic spine), except for one syntype that lacks all post-cephalic spines.

Caruso (1981) recognized ZSI F13467 as the holotype of $L$. lugubris and treated it as junior synonym of Lophiodes 
mutilus. However, according to Alcock (1894), three lots of specimens were used in his description. The first author of present paper examined two other syntypes, ZSI F670/1 and ZSI F671/1, both listed as non-types by Caruso (1981). The former specimen has one post-cephalic dorsal-fin spine and the latter has none, which is consistent with Alcock's original observation. The illicium of ZSI F671/1 is damaged, but the third dorsal-fin spine is long $(58.0 \% \mathrm{SL})$, and the specimen has other characters that distinguish it from L. triradiatus. The first author of present paper examined a series of Indian specimens $(n=21)$ that consistently have four dorsalfin spines, whereas all specimens of L. mutilus (and two closely-related species, L. iwamotoi and L. maculatus) consistently have five dorsal-fin spines (e.g. 2 post-cephalic spines). Hence, we recognize Lophiodes lugubris as a valid species. One of the syntypes, ZSI F13467 is presumed lost.

\section{DISCUSSION}

As mentioned above, only a few lophiid species have been recorded from Indonesian waters, namely Lophiomus setigerus, Lophiodes gralicimanus and Lophiodes mutilus (Caruso 2002). Surprisingly, not many lophiid specimens were collected in the 138 hauls made over a period of about seven and half months during the present study.

Only two specimens of Lophiomus setigerus were collected during the survey, despite the fact that the species is the most common lophiid species in the Indo-west Pacific region [during all seasons]. Only one specimen each of Lophiodes triradius and Lophiodes naresi were collected during this survey although a good number have been regularly collected in the western Pacific Ocean (Ho and Shao 2007; Ho et al. 2009, 2011, 2014).

Only one specimen each of L. endoi, L. miacanthus and $L$. bruchius were collected in the eastern Indonesian region, corresponding with the results of Ho et al. (2011). These three species may be more abundant in waters further north around Taiwan and Japan than in the tropical Pacific region.

By contrast, no specimens identifiable as Lophiodes mutilus were collected during the survey. According to personal observations of the first author, L. mutilus (now recognized as a species complex; Ho, unpub. data) is far more common compared to other congeners in areas such as South Africa, Taiwan, Japan and Australia.

In summary, the low density of lophiid anglerfishes in the eastern Indian Ocean region off Indonesia differs from that observed in oceanic water of many other countries of the Indo-west Pacific region. More investigations are needed to understand the fish fauna of this region.

Key to species of Lophiidae occurring in Indonesian waters

1A. Head and body box-like, only slightly depressed; 2 cephalic spines; no esca present..... Sladenia cf. chui

1B. Head and body strongly depressed; 3 cephalic spines; esca present

2A. Many knobs on dorsal surfaces of frontal and premaxilla Lophiomus setigerus
2B. Dorsal surfaces of frontal and premaxilla smooth, without any knob 3 (Lophiodes)

3A. Dorsal-fin spines 6, post-cephalic spines 3 .............. 4

3B. Dorsal-fin spines 3-5, post-cephalic spines $0-2 \ldots \ldots .5$

4A. Peritoneum white ................. Lophiodes gralicimanus

4B.Peritoneum black Lophiodes naresi

5A No post-cephalic spine; illicium short; esca leaf-like .. Lophiodes triradiatus

5B. One or 2 post-cephalic spines; illicium long; esca bulb-like, with or without cirri ................................ 6

6A. One post-cephalic spine ............. Lophiodes lugubris

6B. Two post-cephalic spines............................................ 7

7A. Illicial stem brown to black; esca transparent

Lophiodes miacanthus

7B. Illicial stem light color, as adjacent body; esca gray or black

8A. Pectoral-fin rays 15-18 (mainly 16); esca a tiny bulb, slightly bigger than diameter of illicial stem; many tendrils on 3rd dorsal-fin spine........Lophiodes mutilus

8B. Pectoral-fin rays $18-22$ (mainly 20-21); esca bulb much larger than the diameter of illicial stem; 1 or 2 pairs of tendril on upper third of 3rd dorsal-fin spine

9A. No cirrus on esca; esca color as adjacent body ground. Lophiodes endoi

9B. Cirri on esca; esca black. Lophiodes bruchius

\section{ACKNOWLEDGEMENTS}

We thank M. Yabe and H. Imamura (Faculty of Fisheries Sciences, Hokkaido University) for making the materials available and M. F. Gomon (NMV) and T. Munroe (USNM) for reading and improving the manuscript. $\mathrm{HCH}$ especially thanks lab mates of the Systematic Ichthyology Laboratory, Graduate School of Fisheries Sciences, Hokkaido University and T. Kawai for their hospitalities during his visit to Hakodate. The visit was supported by Hokkaido University Museum and by the Ministry of Science and Technology, R.O.C. to HCH.

\section{REFERENCES}

Alcock A.W. 1894. Natural history notes from H.M. Indian marine survey steamer, 'Investigator,' Commander C.F. Oldham, R.N., commanding. Series II. No. 9. An account of the deep-sea collection made during the season of 1892-93. Journal of the Asiatic Society of Bengal 62, part 2 (4): 169-184.

Caruso J.H. 1981. The systematics and distribution of the lophiid anglerfishes: I. A revision of the genus Lophiodes with the description of two new species. Copeia 1981: 522-549.

Caruso J.H. 1999. Lophiidae. Anglerfish (monkfish). Pp. 2004-2012. In: Carpenter K.E., Niem V.H. (eds.) FAO Species identification guide for fishery purposes. The living marine resources of the Western Central Pacific. Vol. 3. Batoid fishes, chimaeras and bony fishes. Part 1 (Elopidae to Linophrynidae). FAO, Rome.

Eschmeyer W.N. 2016. Catalog of Fishes. Electronic version. http://researcharchive.calacademy.org/research/ ichthyology/catalog/fishcatmain.asp 
Gilbert C.H. 1905. II. The deep-sea fishes of the Hawaiian Islands. In: The aquatic resources of the Hawaiian Islands. Bulletin of the U.S. Fish Commission 23 (2): 577-713.

Gill T.N. 1883. Supplementary note on the Pediculati. Proceedings of the United States National Museum 5 (316): 551-556.

Goode G.B., Bean T.H. 1896. Oceanic ichthyology, a treatise on the deep-sea and pelagic fishes of the world, based chiefly upon the collections made by the steamers Blake, Albatross, and Fish Hawk in the northwestern Atlantic, with an atlas containing 417 figures. Memoirs of the Museum of Comparative Zoology at Harvard College 22: 1-26 + 1-553.

Günther A. 1880. Report on the shore fishes procured during the voyage of H.M.S. Challenger in the years 1873-1876. In: Report on the scientific results of the voyage of H. M. S. Challenger during the years $1873-$ 76. Zoology 1( 6): 1-82.

Ho H.-C., Bineesh K.K., Akhilesh K.V. 2014. Rediscovery of Lophiodes triradiatus (Lloyd 1909), a senior synonym of $L$. infrabrunneus Smith and Radcliffe (Lophiiformes: Lophiidae). Zootaxa 3786 (5): 587-592.

Ho H.-C., Kawai T., Amaoka K. 2016. Deep-sea anglerfishes (Lophiiformes: Ceratioidei) from Indonesia, with description of three new species. Zootaxa 4121 (3): 267-294.

Ho H.-C., Kawai T., Satria F. 2015. Records of the anglerfish genus Chaunax from Indonesia, with descriptions of two new species (Lophiiformes: Chaunacidae). Raffles Bulletin of Zoology 63: 301-308.

Ho H.-C., Séret B., Shao K.-T. 2009. Redescription of Lophiodes infrabrunneus Smith and Radcliffe 1912, a senior synonym of L. abdituspinus Ni, Wu and Li 1990 (Lophiiformes: Lophiidae). Zootaxa 2326: 62-68.
Ho H.-C., Séret B., Shao K.-T. 2011. Records of anglerfishes (Lophiiformes: Lophiidae) from the western South Pacific Ocean, with descriptions of two new species. Journal of Fish Biology 79 (7): 1722-1745.

Ho H.-C., Shao K.-T. 2007. Taxonomic review of Lophiidae (Pisces: Lophiiformes) in Taiwan. Journal of the National Taiwan Museum 60 (1): 19-32.

Ho H.-C., Shao K.-T. 2008. A new species of anglerfish (Lophiiformes: Lophiidae) from the western Pacific. Ichthyological Research 55 (4): 367-373.

Ho H.-C., Shao K.-T. 2011. Annotated checklist and type catalog of fish genera and species described from Taiwan. Zootaxa 2957: 1-74.

Lloyd R.E. 1909. A description of the deep-sea fish caught by the R.I.M.S. ship 'Investigator' since the year 1900, with supposed evidence of mutation in Malthopsis. Memoirs of the Indian Museum 2 (3): 139-180.

Ni Y., Wu H.-L., Li S. 2012. A new species of the genus Sladenia (Pisces, Lophiidae) from the East China Sea and the South China Sea. Acta Zootaxonomica Sinica 37 (1): 211-216.

Regan C.T. 1908. Report on the marine fishes collected by Mr. J. Stanley Gardiner in the Indian Ocean. The Transactions of the Linnean Society of London, second series, Zoology 12 (3): 217-255.

Smith H.M., Radcliffe L. 1912. New pediculate fishes from the Philippine Islands and contiguous waters. In: Radcliffe L. Scientific results of the Philippine cruise of the Fisheries steamer "Albatross," 1907-1910. No. 16. Proceedings of the United States National Museum 42 (1896): 199-214.

Vahl M. 1797. Beskrivelse tvende nye arter af Bredflabslaegten Lophius. [Description of two new species of bee-lips-genus Lophius.] Skrivter af NaturhistorieSelskabet Kiøbenhavn 4: 212-216.

Received: 13 March 2016 Accepted: 24 May 2016 Published electronically: 30 June 2016 